DOI: https://doi.org/10.11144/Javeriana.umed59-4.piel

\title{
Incidence of Acute Pyelonephritis in Hospitalized Children under 5 Years Old with Positive Urine Culture
}

\section{Incidencia de pielonefritis aguda en menores de 5 años hospitalizados con urocultivo positivo}

Received: August 122015 | Accepted: July 102018

\author{
Alexandra Castaño González ${ }^{\mathrm{a}}$ \\ Hospital Universitario San Ignacio, Colombia \\ Juan Ruiz Peláez \\ Hospital Universitario San Ignacio, Colombia
}

a Correspondence: acastano@javeriana.edu.co

How to cite: Castaño González A, Ruiz Peláez J. Incidence of acute pyelonephritis in hospitalized children under 5 years old with positive urine culture.

Univ. Med. 2018;59(4). doi: https:// doi.org/10.11144/Javeriana.umed59-4.piel

\begin{abstract}
Introduction: Urinary tract infection is a major cause of child morbidity. The diagnosis of acute pyelonephritis is important to decide the treatment. Methods: Retrospective observational study. We collected information of urinalysis, urine Gram and urine culture of hospitalized children between 3 months and 5 years old, with suspected urinary tract infection between January 2008 and December 2010. In patients with positive urine culture, the results of renal scintigraphy (Gamma scan) were evaluated to estimate the incidence of acute pyelonephritis. Results: We identified 1,463 medical records. Urinary culture was obtained in 237 patients, of whom $54.4 \%$ were positive. Renal scintigraphy was obtained in 93 of these patients and 59.1\% were positive. Conclusions: The incidence of acute pyelonephritis in patients with confirmed urinary tract infection was $59.1 \%$.

Keywords

urinary tract infection; acute pyelonephritis; incidence; urine culture; renal
\end{abstract} scintigraphy.

\section{RESUMEN}

Introducción: la infección de las vías urinarias es una causa importante de morbilidad infantil. Establecer si existe pielonefritis aguda es un factor importante para su tratamiento. Materiales y métodos: estudio observacional descriptivo. Se registraron los resultados de uroanálisis, gram de orina y urocultivo de niños entre 3 meses y 5 años de edad hospitalizados con sospecha de infección de las vías urinarias, entre enero de 2008 y diciembre de 2010. En pacientes con urocultivo positivo se evaluó el resultado de la gammagrafía renal, estimando la incidencia de pielonefritis aguda. Resultados: se recolectaron 1.463 historias clínicas y se solicitó urocultivo en 237 . De estas, el 54,4\% fueron positivas para pielonefritis. En 93 casos se tomaron gammagrafías renales, positivas en el $59,1 \%$ de los casos. Conclusiones: la incidencia de pielonefritis aguda en pacientes con infección de las vías urinarias se confirmó en el 59,1\%.

Palabras clave

infección urinaria; pielonefritis aguda; incidencia; urocultivo; gammagrafía renal. 


\section{Introduction}

Urinary tract infection (UTI) is an important cause of child morbidity (1), and in many cases it is an indicator of anatomical urological alterations and a risk factor for the development of renal scars, arterial hypertension and chronic renal failure (2). Before the discovery of antibiotics, mortality due to UTI reached 20\% (2).

A prevalence of UTI between 2.1 and $8.7 \%$ has been documented in patients under 2 years of age who consult the emergency department with fever of unknown origin (3). Infants have a higher risk of acute and chronic complications secondary to UTI, due to the higher incidence of renal scars in this population (4) and the difficulties in diagnosis, taking into account its nonspecific symptoms; in infants, fever, irritability and vomiting are manifestations of both urinary infections and many self-limiting viral diseases (4).

Diagnosing acute pyelonephritis is a factor in determining the appropriate treatment and establishing the prognosis (5). The timely diagnosis of acute pyelonephritis and the time elapsed until initiation of the appropriate therapy contribute to reducing immediate and long-term complications (6). The incidence of secondary renal scars increases with each new episode of acute pyelonephritis, as well as when there is a delay in the diagnosis and initiation of the appropriate antibiotic therapy (5). Renal scars increase the risk of recurrent episodes of acute pyelonephritis, impaired glomerular function, hypertension, and pregnancy-induced hypertension (3).

Renal scintigraphy with dimercaptosuccinic acid (DMSA) is the reference standard for the diagnosis of acute pyelonephritis and renal scars $(7,8)$ and was a compulsory paraclinical examination, considering that until 2010 the treatment of patients with UTI was based on the second edition of the Evidence-based Pediatric Practice Guidelines.

There have been major changes in the treatment of UTI in children between 3 months and 5 years since 2002, and, particularly between
2002 and 2010, the following recommendations were adopted in the hospital:

1. Perform a catheterized urine culture in all patients under 2 years of age who have urinalysis suggestive of UTI, and by spontaneous urination in children aged 2 to 5 years.

2. Perform a kidney ultrasound scan in search of anatomical alterations in all children with positive urine culture.

3. Perform a renal scintigraphy with DMSA in all children with positive urine culture.

According to the Guidelines, a differential treatment according to the current criteria of complicated or uncomplicated UTI was not considered.

\section{Materials and methods}

Objective. To estimate the incidence of acute pyelonephritis, diagnosed with renal scintigraphy with DMSA in children between 3 months and 5 years of age, hospitalized in the Hospital Universitario San Ignacio.

Study population. Children aged between 3 months and 5 years, hospitalized at the Hospital Universitario San Ignacio for UTI confirmed with urine culture, between January 1, 2008 and September 30, 2010.

Inclusion criteria. Age between 3 months and 5 years with diagnosis of UTI confirmed with urine culture. Inpatient management for this type of infection.

The exclusion criteria were those mentioned in the Guidelines, taking into account that these patients received a different diagnostic management:

Chronic pyelonephritis.

Severe urinary malformations.

Neoplasias.

Immunodeficiencies.

History of urinary tract surgery.

Neurogenic bladder.

Diabetes mellitus.

Study design. Observational, descriptive study (historical cohort). 
Outcome variable. Result of renal scintigraphy with DMSA: positive or negative for acute pyelonephritis.

Procedure. A computerized search of doctorpatient encounters in the hospitalization service was performed, of eligible children with tracer diagnoses for UTI, acute pyelonephritis, cystitis, dysuria, oliguria or fever without apparent source. In all the records, information related to urinalysis, urine Gram without centrifugation and urine culture was reviewed. In the records of patients with positive urine culture, the result of the renal scintigraphy was evaluated.

Analysis. Four trained observers extracted the information from the computerized medical records, and an Excel database was created. The SPSS 17 software was used for the analysis. Frequency distributions, incidence proportions and $95 \%$ confidence intervals were generated.

\section{Results}

A total of 3346 care attentions that were candidates to have tracer diagnoses were reviewed, and 1,463 eligible records of care were identified. Of the 1463 patients initially selected, $43 \%$ were treated during 2008; 30.8\% during 2009, and 26.2\% during 2010. Table 1 shows the age distribution of patients from the eligible records of care.

Table 1

Age distribution of patients of the reviewed events

\begin{tabular}{|l|r|r|}
\hline \multicolumn{1}{|c|}{ Age } & n & Frequency (\%) \\
\hline $\begin{array}{l}\text { Under 1 year of } \\
\text { age }\end{array}$ & 532 & 36.4 \\
\hline 1-3 years old & 658 & 45.0 \\
\hline 3-5 years old & 273 & 18.7 \\
\hline Total & 1,463 & 100.0 \\
\hline
\end{tabular}

Urinalysis was performed in $67.9 \%$ ( $\mathrm{n}=$ 993) of the patients and a result suggestive of UTI was obtained in $13.6 \%(\mathrm{n}=136)$ of the children. Urine Gram was performed without centrifugation in $67.3 \%(n=985)$ of the patients; of these, $14.4 \%(\mathrm{n}=142)$ were positive.

Urine culture was performed in 237 patients, of which 129 were positive $(54.4 \%)$. The most frequently recovered germ was E. coli, followed by Proteus sp. (tables 2 and 3).

\section{Table 2}

Results of urine cultures

\begin{tabular}{|l|r|r|}
\hline \multicolumn{1}{|c|}{ Urine culture } & \multicolumn{1}{c|}{ n } & Frequency (\%) \\
\hline Negative & 108 & 45.5 \\
\hline Positive & 129 & 54.4 \\
E. coli & 111 & 86.0 \\
Proteus & 6 & 4.7 \\
Other Gram-negative & 11 & 8.5 \\
Other Gram-positive & 1 & 0.8 \\
\hline Total & 237 & 100.0 \\
\hline
\end{tabular}

Table 3

Results of urine cultures performed according to age

\begin{tabular}{|l|r|r|r|}
\hline \multicolumn{1}{|c|}{ Result } & $\begin{array}{c}\text { Under 1 year of } \\
\text { age [n (\%)] }\end{array}$ & $\begin{array}{c}\text { 1-3 years old } \\
\text { [n (\%)] }\end{array}$ & \multicolumn{1}{c|}{$\begin{array}{c}\text { 3-5 years old } \\
\text { [n (\%)] }\end{array}$} \\
\hline Negative & $37(34.3)$ & $43(49.5)$ & $28(66.6)$ \\
\hline E. coli & $61(56.4)$ & $39(44.8)$ & $11(26.2)$ \\
\hline Proteus & $3(2.8)$ & $2(2.3)$ & $1(2.4)$ \\
\hline Other Gram-negative & $7(6.5)$ & $3(3.4)$ & $1(2.4)$ \\
\hline Other Gram-positive & $0(0.0)$ & $0(0.0)$ & $1(2.4)$ \\
\hline Total & $108(100.0)$ & $87(100.0)$ & $42(100.0)$ \\
\hline
\end{tabular}

According to the Guide for the management of UTI of the Hospital Universitario San Ignacio, all patients under 5 years of age with suspected UTI due to the clinical manifestations and the initial paraclinical examinations (urinalysis and non-centrifuged urine Gram) received inpatient antibiotic management. In the case of those who had a positive urine culture, a renal scintigraphy with DMSA was ordered.

In some cases, it was not possible to recover the result of the DMSA renal scintigraphy (performed in another institution, patient's noncompliance or administrative problems). The results of 93 renal scintigraphies were recovered, of which 55 were positive. In 36 subjects with UTI demonstrated by urine culture, the result of the renal scintigraphy was not recovered. The estimated incidence of acute pyelonephritis in 
patients with positive urine culture was $59.1 \%$ with a $95 \% \mathrm{CI}=48.5 \%-69.2 \%$ (Table 4 ).

\section{Table 4}

Result of renal DMSA scintigraphy according to the age of the patients with positive urine culture

\begin{tabular}{|l|r|r|r|r|}
\hline \multicolumn{1}{|c|}{ Result } & $\begin{array}{c}\text { Under 1 year of } \\
\text { age [n (\%)] }\end{array}$ & $\begin{array}{c}\mathbf{1 - 3} \text { years old } \\
\text { [n (\%)] }\end{array}$ & $\begin{array}{c}\text { 3-5 years old } \\
\text { [n (\%)] }\end{array}$ & $\begin{array}{c}\text { All ages } \\
{[\mathbf{n}(\%)]}\end{array}$ \\
\hline Positive & $30(55.5)$ & $19(63.3)$ & $6(75)$ & $55(59.1)$ \\
\hline Negative & $25(44.0)$ & $11(36.7)$ & $2(25)$ & $38(40.9)$ \\
\hline Total & $55(100.0)$ & $30(100.0)$ & $8(100)$ & $93(100.0)$ \\
\hline
\end{tabular}

\section{Discussion}

In this study, the incidence of acute pyelonephritis in hospitalized patients at the Hospital Universitario San Ignacio for UTI confirmed with urine culture was $59.1 \%$. This finding matches the one that has been reported by several authors, such as Ghasemi et al. (9), who found that $54.7 \%$ of patients hospitalized for UTI had pyelonephritis, and Koufadaki et al. (10), who also documented the presence of pyelonephritis in 51\% of hospitalized children.

In a guide for the management of hospitalized patients with acute pyelonephritis, Chishti et al. (6) indicated that in order to prevent shortand long-term effects it is important to make a timely diagnosis of this entity and promptly initiate the appropriate antibiotic treatment. At the Hospital Universitario San Ignacio, renal scintigraphy with DMSA was indicated in all patients under 5 years of age hospitalized with a confirmed UTI.

According to the clinical practice guidelines for the diagnosis and treatment of UTIs of the National Institute for Health and Clinical Excellence (NICE), in children with bacteriuria and temperature over $38^{\circ} \mathrm{C}$, or with bacteriuria and low back pain, a diagnosis of pyelonephritis should be considered, and in children with bacteriuria, without signs or systemic symptoms, a diagnosis of cystitis should be considered. These Guidelines do not recommend routine imaging of patients with UTI; they mention that in cases where it is important to confirm or exclude pyelonephritis, renal ultrasonography is recommended, and if the diagnosis is not clear with this method, renal scintigraphy with DMSA.

In a systematic review by Cochrane, Shaikh et al. (11) found that there are no biochemical markers to accurately predict the presence or absence of pyelonephritis in patients with UTI. In a study published by Ayazi et al. (12) it was documented that renal ultrasonography was not a useful tool to diagnose pyelonephritis in children hospitalized with UTI (sensitivity of $32 \%$ and specificity of $85 \%$ ).

It is possible that the high incidence of acute pyelonephritis is related to the characteristics of the studied population: patients hospitalized in a reference institution. In view of the foregoing, the results cannot be extrapolated to patients with UTI managed on an outpatient basis or in institutions of a different level.

Considering what the NICE Clinical Guidelines suggest in relation to establishing the diagnosis of acute pyelonephritis based on the presence of symptoms or signs of systemic inflammatory response or low back pain in patients without risk factors, it is important to carry out studies to document the incidence of acute pyelonephritis in patients with UTI, stratifying the population according to systemic signs and symptoms. According to the estimated incidents, it could be considered if renal scintigraphy is justified in patients without systemic involvement.

\section{Conclusions}

In the study population, the incidence of acute pyelonephritis in hospitalized patients with positive urine culture is high $(59.1 \%)$. A sensitivity analysis (worst-best scenario), which evaluates the role in the estimation of the 36 cases of positive urine culture in which renal scintigraphy was not recovered, shows that the incidence would remain high: between $42.6 \%$ (if none of the 36 subjects without data had acute pyelonephritis) and $70.5 \%$ (if the 36 had acute pyelonephritis). 
Additional studies are required in institutions of different complexity levels to define the possibility of extrapolating the findings of this study.

\section{References}

1. National Collaborating Centre for Women's and Children's Health (UK). Urinary tract infection in Children, diagnosis, treatment and long-term management. NICE Clinical Guidelines (n. .54$)$. London: RCOG Press; 2007.

2. Zorc J, Kiddoo D, Shaw K. Diagnosis and management of pediatric urinary tract infections. Clin Microbiol Rev. 2005;18(2):417-22.

3. Shaik N, Morone N, López J, Chianese J, Sangvai S, D'Amico $\mathrm{F}$, et al. Does this child have a urinary tract infection? JAMA. 2007;298(24):2895-904.

4. American Academy of Pediatrics, Committee on Quality Improvement, Subcommittee on Urinary Tract Infection. Practice parameter: The diagnosis, treatment, and evaluation of the initial urinary tract infection in febrile infants and young children. Pediatrics. 1999;103(4):843-52.

5. Quigley R. Diagnosis of urinary tract infections in children. Curr Opin Pediatr. 2009;21:194-8.

6. Chishti A, Maul E, Nazario R, Bennett J, Kiessling S. A guideline for the inpatient care of children with pyelonephritis. Ann Saudi Med. 2010;30(5):341-9.

7. Chiou YY, Wang ST, Tang MJ, Lee BF, Chiu NT. Renal fibrosis: Prediction from acute pyelonephritis focus volume measured at $99 \mathrm{mTc}$ Dimercaptosuccinic Acid SPECT1. Radiology. 2001;221:366-70.
8. Mohkan M, Maham S, Rahmani A, Naghi I, Otokesh B, Raiiati $\mathrm{H}$, et al. Technetium Tc $99 \mathrm{~m}$ dimercaptosuccinic acid renal scintigraphy in children with acute pyelonephritis correlation with other imaging tests. Iran J Kidney Dis. 2010;5(4):297-301.

9. Ghasemi K, Montarezi S, Pashazadeh AM, Javadahi H, Assadi M. Correlation of 99mTc-DMSA scan with radiological and laboratory examinations in childhood acute pyelonephritis: A time-series study. Int Urol Nephrol. 2013;45:925.

10. Koufadaki AM, Karavanaki KA, Soldatou A, Tsentidis Ch, Sourani MP, Sdogou T, et al. Clinical and laboratory indices of severe renal lesions in children with febrile urinary tract infection. Acta Paediatr. 2014 Sep;103(9):e404-9.

11. Shaikh N, Borrel JL, Evron J, Leeflang MM. Procalcitonin, Creactive protein, and erythrocyte sedimentation rate for the diagnosis of acutepyelonephritis in children. Cochrane Database Syst Rev. 2015 Jan 20;1:CD009185.

12. Ayazi P, Mahyar A, Noroozian E, Esmailzadehha N, Barikani A. Comparison of renal ultrasonography and dimercaptosuccinic acid renal scintigraphy in febrile urinary tract infection. Infez Med. 2015 Dec;23(4):323-9. 